doi: $10.26529 /$ cepsj.342

\title{
Primary Teacher Students' Understanding of Fraction Representational Knowledge in Slovenia and Kosovo
}

Vida Manfreda Kolar ${ }^{1}$, Tatjana Hodnik Čadež ${ }^{1}$ and Eda Vula ${ }^{* 2}$

$\approx$ The study of primary teacher students' knowledge of fractions is very important because fractions present a principal and highly complex set of concepts and skills within mathematics. The present study examines primary teacher students' knowledge of fraction representations in Slovenia and Kosovo. According to research, there are five subconstructs of fractions: the part-whole subconstruct, the measure subconstruct, the quotient subconstruct, the operator subconstruct and the ratio subconstruct. Our research focused on the part-whole and the measure subconstructs of fractions, creating nine tasks that were represented by different modes of representation: area/region, number line and sets of objects. The sample consisted of 76 primary teacher students in Slovenia and 93 primary teacher students in Kosovo. Both similarities and differences of the primary teacher students' interpretations of the representations across the two countries were revealed and compared. The findings suggest that primary teacher students from both countries need to upgrade their understanding of fractions. The analysis confirms that the formal mathematical knowledge acquired by primary teacher students is not necessarily adequate for teaching elementary concepts in school.

Keywords: primary teacher student, fraction, representation, partwhole subconstruct, measure subconstruct

1 University of Ljubljana, Faculty of Education, Slovenia.

$2{ }^{\star}$ Corresponding Author. University of Prishtina, Faculty of Education, Kosovo; eda.vula@uni-pr.edu. 


\section{Razumevanje reprezentacij o ulomkih pri študentih razrednega pouka v Sloveniji in na Kosovu}

Vida Manfreda Kolar, Tatjana Hodnik Čadež in Eda Vula

$\propto$ Preučevanje razumevanja ulomkov pri študentih razrednega pouka je izjemnega pomena, saj ulomki predstavljajo temeljni in hkrati zelo kompleksen sistem konceptov in veščin znotraj matematike. $\mathrm{V}$ tej raziskavi smo raziskali razumevanje reprezentacij o ulomkih med študenti razrednega pouka iz Slovenije in Kosova. Na osnovi raziskav s področja ulomkov je znano, da obstaja pet podkonceptov ulomkov: podkoncept del - celota, podkoncept merjenja, kvocientni podkoncept, podkoncept operacije in podkoncept razmerja. $\mathrm{V}$ naši raziskavi smo se osredinili na podkoncepta del - celota in merjenja ter sestavili devet nalog, ki so ustrezale različnim načinom reprezentacije ulomka: ploskovni model, številska os in množica objektov. Vzorec v raziskavi je predstavljalo 77 slovenskih in 93 kosovskih študentov razrednega pouka. Rezultati razkrivajo nekatere podobnosti in razlike pri interpretacijah reprezentacij $\mathrm{v}$ obeh državah in nakazujejo, da bi bilo treba izboljšati razumevanje ulomkov pri študentih razrednega pouka obeh držav. Analiza potrjuje, da formalno matematično znanje, ki so ga ti študentje pridobili med izobraževanjem, ni zadostno za ustrezno poučevanje osnovnih pojmov o ulomkih v šoli.

Ključne besede: študent razrednega pouka, ulomek, reprezentacija, podkoncept del - celota, podkoncept merjenja 


\section{Introduction}

Fractions represent a highly complex set of concepts within mathematics (Behr, Post, Harel, \& Lesh, 1993; Charalambous \& Pitta-Pantazi, 2007; Hallett, Nunes \& Bryant, 2010; Van Steenbrugge, Valcke, \& Desoete, 2014). They are a very important topic in elementary mathematics because the idea of fractions is crucial for developing an understanding of other mathematical concepts, including algebra and probability (Clarke, Roche, \& Mitchell, 2007). However, the understanding of fractions continues to be a challenging topic both for learning and for teaching (Ma 1999; National Mathematics Advisory Panel 2008; Newton, 2008). Research in this area (Clarke, Roche, \& Mitchell, 2007; Pantziara \& Philippou, 2012) shows that children have a weak conceptual understanding of fractions and of decimal numbers. This is especially problematic in light of the fact that children have many everyday life experiences with fractions before they are introduced to formal teaching and learning about them (Steffe \& Olive, 2010).

Several studies have determined that teachers' knowledge directly influences the learning of fractions by students (Ball, 1990; Barmby, Harries, Higgins, \& Suggate, 2009; Hill, Rowan, \& Ball, 2005; Lin, Becker, Byun, \& Ko, 2013; Son \& Lee, 2016; Van Steenbrugge et al., 2014). Therefore, international educational debate has stressed the importance of high-quality teaching as a central element in the quality of the education system (OECD, 2016).

In recent years, there have been ongoing reforms in the field of education at all levels. One of the conditions for accreditation of a Higher Education Institution in Kosovo is the comparability of studies with those in the European Higher Education Area (EHEA). Thus, the Faculty of Education in Pristina, Kosovo has adapted a curriculum for teacher education programmes comparable with programmes offered at the Faculty of Education in Ljubljana, Slovenia.

Since the primary teacher education curriculum should be linked with the primary education curriculum, below we present a brief description of the Slovenian and Kosovar primary school curriculum with regard to the teaching and learning of fractions.

In both countries, pupils begin to learn about fractions in the second grade (age seven), when they are introduced to the idea of a whole being divided into two, three or four equal parts. In all of these early cases, the whole is represented by a model of pizza or chocolate, and the parts are congruent. Thus, the pupils are given the concrete example of sharing equal parts of certain objects with two, three or four other people.

In the third grade, based on the Slovenian curriculum, pupils begin to learn about other parts (sixths and eighths, for example), but with only one 
part of a given whole (not, for example, 3/8). In Kosovo, based on third-grade programme content, fractions that show equal parts of the whole $(1 / 2,1 / 3,2 / 3$, $3 / 4,4 / 4)$ are taught, as well as fractions showing the same number $(1 / 2,2 / 4,3 / 6)$ and the representation of fractions on a number line.

In the fourth grade, pupils in Slovenia begin to work with calculations such $1 / 5$ of $x=$ or $1 / 5$ of $35=x$, while in the fifth grade, these exercises are extended to defining more parts of a given whole numerically or finding a whole if the value of the parts is given. In Kosovo, the fourth-grade programme includes a reinforcement of the third-grade knowledge of fractions and the comparison of fractions (with the same denominator and with the same numerator). In the fifth grade, the Kosovo curriculum includes fractions as part of a number $(2 / 3$ of 12) as well as operations with fractions, adding and subtracting fractions with the same denominator and with different denominators.

Thus, fractions are introduced in the primary school curriculum in both countries mostly in similar ways, except for in the fifth-grade programme, where Kosovar pupils are also required to perform addition and subtraction with fractions.

Since the part-whole subconstruct is the most common representation of fractions in primary school (Alajmi, 2012; Kieren, 1993), as well as being the representation that children perform consistently better in comparison to the other representations (Charalambous \& Pitta-Pantazi, 2007), the focus of the present study is Slovenian and Kosovar primary teacher students' knowledge of fraction representation in relation to part-whole interpretation. In addition, it was important to consider fractions as measures, due to the role that successively partitioning the unit in a number line has in the other interpretations of fractions (Lamon, 2012). It is expected that the study will provide an insight into primary teacher students' understanding of fundamental fraction knowledge, such as their understanding of the conceptual meaning of fractions and their representations. The findings could offer a basis for improving mathematics programmes for primary teacher students in both countries.

\section{Theoretical background}

\section{Interpretations and representations of fractions}

Fractions are one of the most challenging topics in primary school. The main reason for pupils' difficulties when learning about fractions is the complex idea of what a fraction is (Empson \& Levi, 2011; Lamon, 2012; Kieren, 1993; Pantziara \& Philippou, 2012; Steffe \& Olive, 2010). There are many different aspects of fractions, all of which emphasise a particular meaning of a rational number: 
1. Fractions as dividing a given whole (area, length, set of objects) into equal parts or subsets (the part-whole subconstruct according to Kieren, 1976). This aspect includes discrete area and line models and is known as the part-whole relationship. The concept structure of this relationship involves three components (Castro-Rodriguez, Pitta-Pantazi, Rico, \& Gómez, 2016): the whole, each of the equal parts, and the complementary part or parts.

2. Fractions as positions on a number line (measure subconstruct according to Kieren, 1976). In this case, a fraction is presented as an abstract number with no obvious relationship to the interpretation of fractions defined above.

3. Fractions as a result of division (quotient subconstruct according to Kieren, 1976). Pupils rarely make the connection between fractions and the idea of dividing natural numbers.

4. Fractions as operators (operator subconstruct according to Kieren, 1976), for example, 4/5 of 20.

5. Fractions as ratios (ratio subconstruct according to Kieren, 1976). Understanding this aspect of fractions is important to understanding equality as it relates to fractions, decimal numbers and percentages.

The developmental framework of fraction schemes described by Steffe and Olive (2010) represents the levels of reasoning about fractions within the part-whole subconstruct:

- $\quad$ parts of the whole fraction scheme (includes partitioning of the whole);

- $\quad$ part-whole fraction scheme (includes partitioning and disembodying taking a part out of a whole and using a part to name it as a fractional part of a whole);

- $\quad$ partitive unit fraction schemes (includes partitioning, disembedding, iterating) - by iterating the fractional unit we can construct the whole again;

- $\quad$ partitive fractional scheme (going beyond unit fractional cases; for example representing 3/4);

- $\quad$ iterative fractional scheme (a splitting operation is added to all of the previous operations and the coordination of the three levels of the unit is necessary; for example, representing 5/4).

Based on different fraction subconstructs, and considering the development of fraction schemes, there are many ways that fractions can be represented. According to Castro-Rodrigues, Pitta-Pantazi, Rico and Pedro (2016), 
representations are thought of as a tool in the process of forming the meaning of concepts, which is closely related to pupils' conceptual knowledge (Son \& Lee, 2016).

Van de Wale, Karp and Bay-Williams (2010) provide three types of models/representations for fractions: area or region models, length or linear measurement models, and set models. Popular area or region models include circular "pie" pieces, rectangular regions, pattern blocks and paper folding. Fraction strips, number lines and line segment drawings can be used as length or measurement models and the common set model uses counters (Lamon, 2012; Son \& Lee, 2016). According to National Mathematics Advisory Panel (2008), one key mechanism linking conceptual and procedural knowledge of fractions is the ability to represent them on a number line. Representing fractions on a number line improves the pupils' ability to bridge numerical and spatial properties and facilitates a deeper knowledge of magnitude concepts (Hamdan \& Gunderson, 2017).

Since the part-whole subconstruct has a special role as a source of the notion of the fraction (Castro-Rodrigues, et al., 2016), increased attention should be devoted to studies that focus on the meaning of the fraction concept based on the part-whole subconstruct. The part-whole subconstruct is also the most frequently used interpretation of fractions in primary school exercises books (Alajmi, 2012), as well as being the interpretation that children perform consistently better compared to the other interpretations (Charalambous \& Pitta-Pantazi, 2007).

We argue that, even among part-whole subconstruct problems, different factors influence the pupils' success in solving a problem. Other studies report the problems that arise from the choice of models to represent fractions and the number of parts into which the model is divided. Using vertical parallel lines to create fractions of a rectangular region is correct, but the same method does not work with circular regions (Pothier \& Sawada, 1983). Therefore, the shape of the model/ representation plays an important role in children's understanding of fractions.

Tunç-Pekkan (2015) investigated the role of external graphic representations in pupils' fractional knowledge. She wanted to find out how children perform in parallel fractional knowledge problems that use different graphic representations (circle, rectangle or number line). Her findings indicated that pupils performed similarly on circles and rectangles that required part-whole fractional reasoning, but their performance was significantly poorer on problems with number line as a graphical representations that required an understanding of fractions as abstract numbers. Many other researchers have also found that a rectangular model makes it easier for pupils to deal with fractions (e.g., Keijzer \& Terwel, 2001; Moss \& Case, 2011). Saxe, Taylor, McIntosh and Gearhart (2005) 
investigated the developmental relationship between pupils' use of fraction notation and their understanding of part-whole relations, demonstrating the advantage of the role of presenting fractions to students using parts of an area.

Piaget, Inhelder and Szeminska (1960) investigated the role of linear versus non-linear fractional representations. Working with three-year-old children, they discovered that successfully dividing a non-linear shape (such as a circle) into two halves comes a year later developmentally than dividing a linear object into two parts. There does appear to be a big leap developmentally between dividing a whole into two and three equal pieces. According to Piaget et al. (1960), children between the ages of four and four-and-a-half usually succeed in dividing a whole into two equal parts, but cannot divide it into three equal parts. The latter problem requires the ability to perform operations that produce the initial number sequence (Piaget et al., 1960).

These results suggest not only that it is easier for pupils to understand the part-whole sub-construct of fractions than other aspects of fractions, but that different factors within the part-whole subconstruct may influence pupils' success in a given problem: for example, representations of areal shapes, linear and non-linear approaches, number of parts, etc.

\section{Primary teacher students' knowledge of fractions}

Teacher knowledge is an important element in pupils' learning. It should be focused both on subject (content) knowledge and pedagogical content knowledge, as well as on connections between the two (Shulman, 1986). Regarding mathematics knowledge for teaching, especially knowledge of fractions, many researchers have shown that both inservice and preservice teachers have difficulties with the concept of fractions (Ball, 1990; Hill, Schilling, \& Ball, 2004; Ma, 1999; Van Steenbrugge et al., 2010).

Several researchers (Ball, 1990; Lin at al., 2013; Newton, 2008; Yang et al., 2009; Tsao, 2005; Van Steenbrugge et al., 2014) have reviewed primary teacher students' difficulties involving procedural and conceptual knowledge of fractions. In their study, Vula and Kingji-Kastrati (2018) showed that primary teacher students had a limited knowledge of different fraction interpretations and of the explanation of the procedures for adding and subtracting fractions.

Olanoff, Lo and Tobias (2014) discussed 43 articles focusing on primary teacher students' fraction knowledge. They found that primary teachers students' knowledge is relatively strong when it comes to performing procedures, but that they generally lack flexibility in moving away from procedures and using "fraction number sense". Many teachers emphasise the syntactic (rules) rather than the semantic (meaning) in doing fraction operations to develop a 
sense of rational numbers (de Castro, 2008). However, the research of Manfreda Kolar, Janežič and Hodnik Čadež (2015) revealed just the opposite: primary teacher students had more problems with procedural rather than conceptual understanding of fractions when comparing fractions. Students were aware of the importance of the fixed whole in the real-life situation but lacked the appropriate procedure to compare them when a comparison of two numbers was presented to them. In their study, Bobos and Sierpinska (2017) supported a gradual process of abstraction of the notion of a fraction as an abstract number that represents a measure of the relationship between two quantities. For them, it is important to help primary teacher students to connect the material and the formal parts of their conceptions of fractions. Regarding the qualities that make teacher education effective, the National Mathematics Advisory Panel (2008) recommended that "a sharp focus be placed on systematically strengthening teacher preparation, early career mentoring and support, and ongoing professional development for teachers of mathematics at every level, with special emphasis on ways to ensure appropriate content knowledge for teaching" (p. 40). Primary teacher students' education is a critical time for deepening teachers' knowledge (Ma, 1999). In recent years, many researchers have therefore continued to address the different approaches to extending whole numbers to fractions implicitly in mathematics courses for primary teacher students. This has led students to reproduce implicitness in their future teaching (Bobos \& Sierpinska, 2017; Castro-Rodrigues, et al., 2016; Chinnappan and Forrester, 2014; Lin et al., 2013; Park, Güçler, \& McCrory, 2013; Van Steenbrugge et al., 2014).

The present study seeks to determine Slovenian and Kosovar primary teacher students' performance in tasks of the part-whole and measure subconstructs of fractions. In addition, the study examines the type of shapes that the primary teacher students used to represent fractions.

\section{Research questions}

In the present study, the focus is on analysis of Slovenian and Kosovar primary teacher students' knowledge on fraction representation. Specifically, the study addresses the following questions:

1. How do primary teacher students from Slovenia and Kosovo perform in tasks regarding the part-whole and measure subconstructs of fractions?

2. In which "direction" do the primary teacher students perform better from part to whole or from whole to part using different representations of fractions?

3. How is the shape of the representation of fractions related to the primary teacher students' success in solving a task? 
4. What type of shape of representations do the primary teacher students use for representing fractions?

\section{Methodology}

The study was based on the descriptive and qualitative non-experimental methods of pedagogical research. The primary teacher students' understanding of fractions was analysed on the basis of their written work (solving tasks and writing notes thereof).

\section{Participants}

The data were collected from 169 primary teacher students in Slovenia from the University of Ljubljana $(\mathrm{N}=76)$ and in Kosovo from the University of Pristina $(\mathrm{N}=93)$. Both groups were primary teacher students trained to teach grades $1-5$ of primary schools. The participants were second-year students who had not been taught the didactics of mathematics at the time of taking the knowledge test on fractions.

In both Kosovo and Slovenia, primary school teachers for grades 1-5 are all-round teachers, and primary teacher students are therefore trained in all school subjects, including mathematics. The Primary Bachelor's degree is a four-year study programme. During this time, as well as subjects and pedagogical courses, primary teacher students also complete teaching practice. In Kosovo and Slovenia, primary teacher students participate in a mathematics course in their first year (the focus of this course is on deepening certain mathematical concepts, not necessarily connected to concepts needed for teaching mathematics). In both countries, the first course on teaching mathematics is taught in the second year, while the second course on teaching mathematics is taught in the last (fourth) year in Kosovo and in the third year in Slovenia. The primary teacher students from both countries involved in the present study had completed the mathematics course on elementary algebraic and geometrical concepts and were about to start the course on teaching mathematics in primary school, which includes teaching fractions.

\section{Instruments and measures}

All of the participants in the study took a paper-and-pencil test with nine tasks that generally covered the part-whole subconstruct of fractions. The exception was Task 4, which was related to the understanding of fractions as measures. The part-whole subconstruct was chosen because it is the most commonly used for fraction interpretation when introducing fractions in primary school. 
Since any fraction interpretation can come close to the power of a number line for building number sense (Lamon, 2012), we chose Task 4 to understand the primary teacher students' knowledge of fractions as measure interpretation.

The part-whole subconstruct is represented through the area model and the set of objects model, whereas the measure subconstruct is represented through the linear model.

Table 1 provides a summary of the nine test tasks in relation to the research questions posed.

Table 1

Distribution of the tasks according to the research questions

\begin{tabular}{|c|c|}
\hline Research Question & Task \\
\hline $\begin{array}{l}\text { 1. How do primary teacher students from Slovenia and } \\
\text { Kosovo perform in tasks regarding the part-whole and } \\
\text { measure subconstructs of fractions? }\end{array}$ & All tasks except 5 and 9. \\
\hline $\begin{array}{l}\text { 2. In which "direction" do the primary teacher students } \\
\text { perform better - from part to whole or from whole to } \\
\text { part using different representations of fractions? }\end{array}$ & $\begin{array}{l}\text { Task } 1 \text { (area representation) } \\
\text { Task } 2 \text { (set of objects representation) } \\
\text { Task } 4 \text { (number line representation) }\end{array}$ \\
\hline $\begin{array}{l}\text { 3. How is the shape of the representation of fractions } \\
\text { related to the primary teacher students' success in solv- } \\
\text { ing a task? }\end{array}$ & $\begin{array}{l}\text { Tasks: } \\
6 \mathrm{~d}, 8 \mathrm{a}, 8 \mathrm{~b}, 8 \mathrm{c} \text { (shape is a circle) } \\
3,6 \mathrm{a}, 6 \mathrm{c} \text { (shape is a rectangle) } \\
6 \mathrm{~b}, 8 \mathrm{~d}, 8 \mathrm{e}, 8 \mathrm{f} \text { (shape is a triangle) } \\
7 \text { (non-typical shape) }\end{array}$ \\
\hline $\begin{array}{l}\text { 4. What type of representations do the primary teacher } \\
\text { students use for representing fractions? }\end{array}$ & Tasks 5 and 9. \\
\hline
\end{tabular}

\section{Results}

We first present the primary school students' success in each task, and then answer the research questions accordingly.

All of the tasks except Tasks 5 and 9 were scored dichotomously: correct/ incorrect. In Task 8, only responses to the three correct options were considered $(8 \mathrm{c}, 8 \mathrm{~d}, 8 \mathrm{f})$. Tasks 5 and 9 differ from the others in that they require the students to present their own representations of fractions; therefore, the results of these two tasks were analysed qualitatively.

As indicated above, the first research question of the study was intended to identify how primary teacher students from Slovenia and Kosovo perform in tasks regarding fractions (part-whole and measure subconstructs). A t-test was used to compare the results of the Slovenian and Kosovar students' performance, with the exception of Tasks 5 and 9, which were analysed qualitatively. Table 2 
Success of Slovenian and Kosovar primary teacher students in solving tasks regarding representations of fractions and comparison of the results

\begin{tabular}{|c|c|c|c|c|c|}
\hline \multirow[t]{2}{*}{ Task } & \multicolumn{2}{|c|}{$\begin{array}{c}\text { Slovenia } \\
(\mathrm{N}=76)\end{array}$} & \multicolumn{2}{|c|}{$\begin{array}{l}\text { Kosovo } \\
(\mathrm{N}=93)\end{array}$} & \multirow[t]{2}{*}{$\alpha$} \\
\hline & Mean & SD & Mean & SD & \\
\hline $\begin{array}{l}\text { 1. a. The rectangle below represents } 3 / 4 \text { of the whole. Draw } 1 \frac{1 / 4}{\text { of }} \text { the } \\
\text { whole. }\end{array}$ & .87 & .34 & .31 & .46 & \\
\hline $\begin{array}{l}\text { b. The rectangle below represents } 13 / 4 \text { of the whole. Mark } 1 / 2 \text { of the } \\
\text { whole. }\end{array}$ & .68 & .46 & .15 & .36 & .000 \\
\hline
\end{tabular}

2. a. The counters below represent $2 / 3$ of the counters. Draw $1 \frac{1}{3}$ of the

$\begin{array}{llll}.91 & .29 & .55 & .50\end{array}$ counters.

\section{८०}

$\begin{array}{llllllll}\text { b. The counters below represent } 24 / 5 \text { of the counters. Mark } 2 / 5 \text { of the } & & .86 & .35 & .27 & .44 & .000\end{array}$ counters.

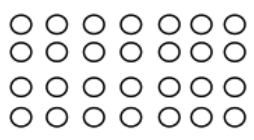

3. On which rectangles do the shaded parts represent $2 / 3$ ? Circle them.

(a)

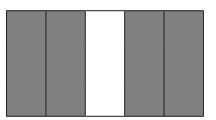

(b)

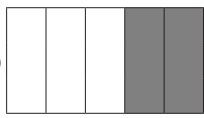

(c)

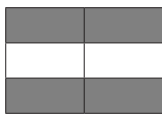

$\begin{array}{llll}.99 & .11 \quad .83 & .37\end{array}$

.001

4a. Mark $1 \frac{1}{7}$ on the number line below.

$\begin{array}{lllll}.97 & .16 & .65 & .48 & .000\end{array}$

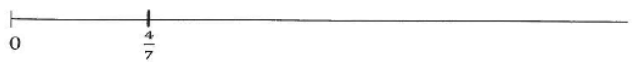

4b. Mark $1 / 3$ on the number line below.

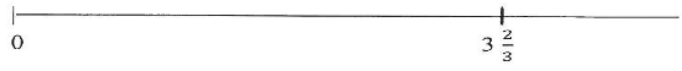

6. Which part of the shape is shaded? Write with a fraction.
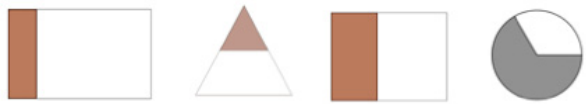

$\begin{array}{lllll}\text { a. } .95 & .22 & .90 & .29 & .278 \\ \text { b. } .67 & .47 & .37 & .48 & .000 \\ \text { c. } .71 & .45 & .77 & .42 & .369 \\ \text { d. } .72 & .45 & .73 & .44 & .948\end{array}$

a.

b.

c.

d. 


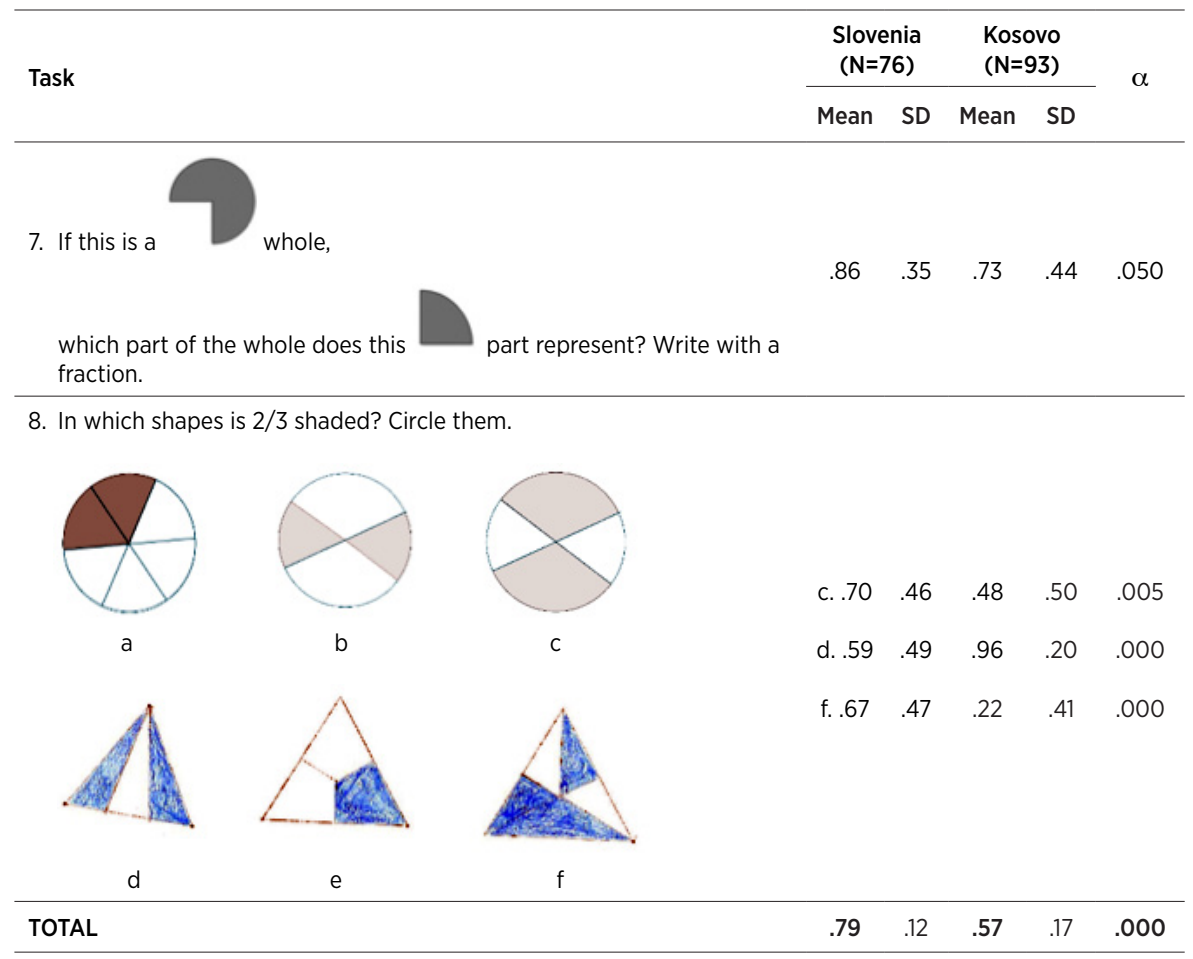

Comparison of the results of the two groups of primary teacher students in all of the above tasks shows that they are statistically different $(t(166)=9.21$, $\mathrm{p}<0.05)$. The students from Slovenia achieved better results than the students from Kosovo in almost all of the tasks. Table 2 indicates that the difference was not significant only in tasks $4 \mathrm{~b}, 6 \mathrm{a}, 6 \mathrm{c}$ and $6 \mathrm{~d}$ ( $\mathrm{p}>0.05$ ), although the primary teacher students from Slovenia achieved a better average in these tasks, as well.

The second research question dealt with the direction of solving the task - from part to whole or from whole to part using different representations of fractions. Three different types of representation were used: area (Task 1), set of objects (Task 2), which correspond to the part-whole subconstruct, and a number line, which corresponds to the measure subconstruct (Task 4). For each type of representation, the task included two subtasks: one dealing with the direction from part to whole and the other dealing with the direction from whole to part. Table 3 focuses on the primary teacher students' success with regard to both criteria (direction and type of representation). For greater clarity, we have presented the results from Table 2 that refer to the second research question. 
Table 3

Success in Tasks 1, 2 and 4 according to the direction of solving the task and the type of representation

\begin{tabular}{lcccc}
\hline Representation of fraction & \multicolumn{2}{c}{ Part to whole [\%] } & \multicolumn{2}{c}{ Whole to part [\%] } \\
\cline { 2 - 5 } & $\begin{array}{c}\text { Slovenia } \\
\mathrm{N}=76\end{array}$ & $\begin{array}{c}\text { Kosovo } \\
\mathrm{N}=93\end{array}$ & $\begin{array}{c}\text { Slovenia } \\
\mathrm{N}=76\end{array}$ & $\begin{array}{c}\text { Kosovo } \\
\mathrm{N}=93\end{array}$ \\
\hline area & 86.8 & 31.2 & 68.4 & 15.1 \\
set of objects & 90.8 & 54.8 & 85.5 & 26.9 \\
number line & 97.4 & 64.5 & 71.1 & 67.7 \\
\hline
\end{tabular}

It can be seen that both groups of primary teacher students performed better in tasks from the part to whole direction (Tasks: 1a, 2a, 4a) than in tasks from the whole to part direction (Tasks: $1 \mathrm{~b}, 2 \mathrm{~b}, 4 \mathrm{~b}$ ) (Table 2). With regard to the type of representation, we can see that, in both groups of students, the task using the number line was solved better than the tasks with the area representation or the set of object representation (Table 3 ) when the part to whole direction was addressed. We believe that these results are connected with the students' experience of using a number line after their primary education. In addition, the measure interpretation of fractions seems to be easier for most of the students in both countries.

Some examples of the primary teacher students' work on these three different types of representations are presented below. Examples that reveal a different approach have been selected. 
1.

a. Narisan pravokotnik predstavlja $\frac{3}{4}$ celote.

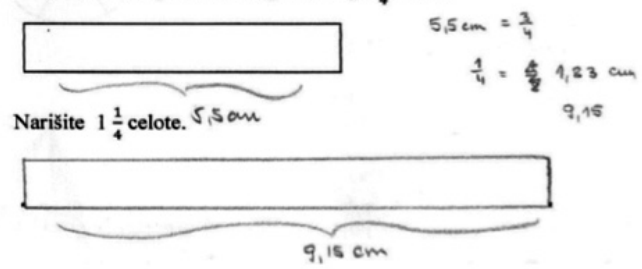

a.

a. Drejtkëndëshi i mëposhtëm paraqet $\frac{3}{4}$ e tërësisë.

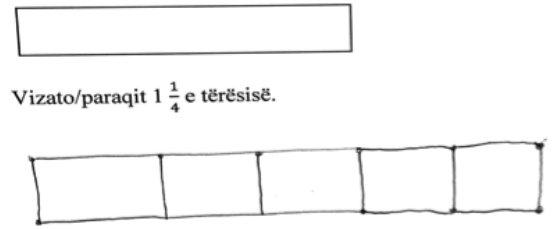

C.

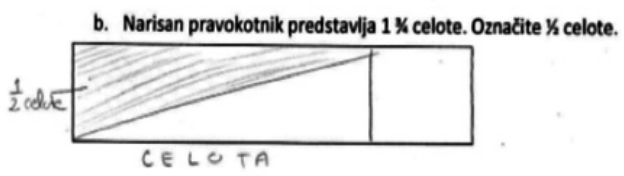

b.

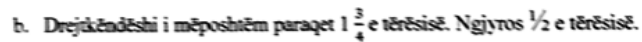

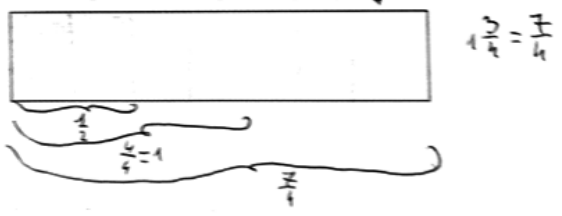

d.

Figure 1. Sample answers to Tasks ia (draw a whole) and $1 \mathrm{~b}$ (draw a part). Examples of dividing a rectangle: a. first measuring and then dividing the numbers; b. measuring the whole, then dividing it in half; c. dividing the whole into equal parts; $d$. measuring the distance.

a. Narisani krožci predstavljajo $\frac{2}{3}$ celote krožcev, Narišite $1 \frac{1}{3}$ krožcev.

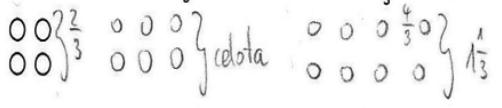

b. Narisani krožci predstavljajo $2-\frac{4}{5}$ celote. Označi $\frac{2}{5}$ celote.

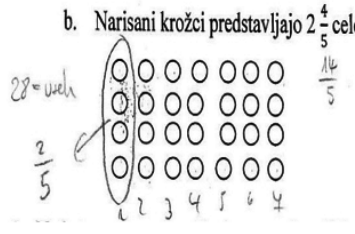

a. Rrathët e mëposhtme paraqesin $\frac{2}{3}$ e tërësisë. Vizato $1 \frac{1}{3} \mathrm{e}$ tërësisë $00 \quad 1 \frac{1}{3}=\frac{4}{3} 71$

b. Rrathët e mëposhtme paraqesin $2 \frac{4}{5} \mathrm{e}$ tërësisë. Ngjyros $\frac{2}{5} \mathrm{e}$ tërësisê $a=\begin{array}{llllllll}0 & 0 & 0 & 0 & 0 & 0 & 0 \\ 0 & 0 & 0 & 0 & 0 & 0 & 0 \\ 0 & 0 & 0 & 0 & 0 & 0 & 0 \\ 0 & 0 & 0 & 0 & 0 & 0 & 0\end{array}$

Figure 2. Sample answers to Tasks $2 \mathrm{a}$ (mark the whole) and $2 \mathrm{~b}$ (mark a part). Examples of dividing a set of objects.

In both cases, the primary teacher students found the solutions after converting the mixed numbers to improper fractions. We found that almost all of the answers to Task $2 \mathrm{~b}$ were the same. The primary teacher students from both countries changed the mixed number $24 / 5$ to an improper fraction and then provided descriptions of $14 / 5$ such as " $24 / 5$ means seven copies of $2 / 5$ ". 
a. Označite $1 \frac{1}{7}$ na številski premici.

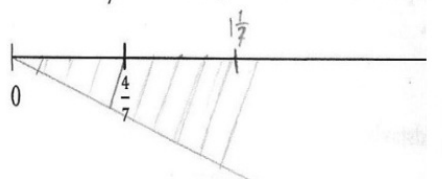

5.

a. Gjeję $1 \frac{1}{7}$ në boshtin numerik tê mểposhtëm.

$$
1 \frac{1}{7}=\frac{7+1}{7}=\frac{8}{7}
$$

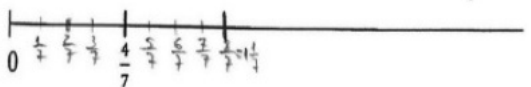

b. Gjjęe $\frac{1}{3}$ në boshtin numerik tể mêpposhtëm.

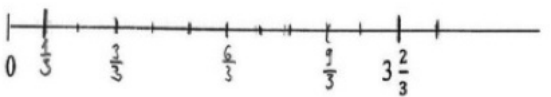

a.

b.

Figure 3. Sample answers to Tasks 4a (mark the whole) and $4 \mathrm{~b}$ (mark a part). Examples of dividing the number line: a. the use of the geometrical method for dividing the line; $b$. placing fractions on the number line was based on the fraction magnitude concept.

Our third research question focused on using different shapes for representations of fractions. We were interested in determining how the shape of the representation of a fraction related to the primary teacher students' success in solving a task. Three shapes of representation were included: rectangle (Tasks $3,6 \mathrm{a}, 6 \mathrm{c}$ ), circle (Tasks 6d, 8a, 8b, 8c) and triangle (Tasks 6b, 8d, 8e, 8f) as well as one non-typical shape (Task 7). Tasks 3 and all of the examples of Task 8 are comparable; only the shape of the representation varies. The students had to recognise the correct representation of the given fraction. In the examples where fractions were represented as parts of rectangles and circles, there was only one correct solution, whereas examples represented as triangles included two correct solutions. We therefore measured success for each example separately. In the example with non-typical presentation, the expression non-typical refers to the shape of the whole, which is represented by three quarters of a circle. The results for both countries are presented in Table 4. 
Table 4

Success in solving the tasks with different types of area representation

\begin{tabular}{lcc}
\hline \multirow{2}{*}{ Shape of representation } & \multicolumn{2}{c}{ Correct solution in (\%) } \\
\cline { 2 - 3 } & Slovenia (N=76) & Kosovo (N=93) \\
\hline Rectangle & 98.7 & 82.8 \\
Task 3 & 94.7 & 89.2 \\
Task 6a & 71.1 & 76.3 \\
Task 6c & 88.2 & 82.8 \\
\hline average & & \\
\hline Circle & 72.4 & 72.1 \\
Task 6d & 69.7 & 48.4 \\
Task 8c & 71.1 & 60.3 \\
\hline average & & \\
\hline Triangle & 67.1 & 36.6 \\
Task 6b & 59.2 & 95.7 \\
Task 8d & 67.1 & 21.5 \\
Task 8f & 64.5 & 51.3 \\
\hline average & & \\
\hline Non-typical & 85.5 & 73.1 \\
\hline Task 7 & & \\
\hline
\end{tabular}

From the results above, we can observe that the shape used for the representation of a fraction does in fact influence the success in solving the task: the rectangle precedes the circle, and the triangle is the least "successful representation" among the shapes. Our results match those of other studies (Piaget, Inhelder, \& Szeminska, 1960; Pothier \& Sawada, 1983), which showed that the rectangle is the easiest shape for developing initial fractional knowledge.

The shape in Task 7 was non-typical, and we therefore expected a lower rate of success compared to typical shapes of representation. Nonetheless, the results show that only the tasks with rectangular representation were solved better, which is not surprising. However, if we look closely at the representations for the circle and the triangle, we see that, although the whole is typical, the division of the shape is not, because the shaded part is not presented in one piece. We can therefore conclude that the lower success rate is due not only to the non-typical whole but also to the non-typical division of the whole. As was found by Vula and Kastrati-Kingji (2018), when a single fractional "part-whole concept" takes different appearances, it seems to be incomprehensible even for primary teacher students.

Example $8 \mathrm{~b}$ deserves special attention. We can see that this was the worst solved example among the Slovenian students, whereas it was ranked as the best-solved example among the Kosovar students. Further discussion with 
the students after the completion of the test, as well as some written explanation of their work, revealed the possible reasons for these unusual results. This was an example of a triangle divided into three non-congruent parts with the same base length. In fact, the triangle is divided into three equal area parts, because they all have the same base length and the same height. However, the students often developed one of the following types of reasoning:

- $\quad$ Focusing only on the base length and overlooking the importance of the height: this type of reasoning led the students to the correct answer, even if they were not aware of the role of the height.

- $\quad$ Focusing on the shape of the three parts, which were not congruent, led the students to the conclusion that the shape was not divided into equal parts. They overlooked the importance of the area size rather than the congruency of the parts.

- $\quad$ Focusing only on dividing the whole into three parts (even though they were not aware that the parts were equal) led them to the correct answer.

Finally, the fourth research question dealt with the primary teacher students' own representations of fractions, that is, we wanted to investigate what type of representations the primary teacher students used for representing fractions.

In Task 5, the students were asked to represent the fraction $4 / 5$ in three different ways, and to explain how the representations differ from each other. Table 5 presents the most commonly used ways of representing fractions.

Table 5

Primary teacher students' representations of the fraction 4/5

\begin{tabular}{lcc}
\hline & $\begin{array}{c}\text { Slovenia (N=76) } \\
(\%)\end{array}$ & $\begin{array}{c}\text { Kosovo (N=93) } \\
(\%)\end{array}$ \\
\hline Rectangular shape & 78.9 & 68.8 \\
Circular shape & 35.5 & 45.2 \\
Set of objects & 56.6 & 26.9 \\
Number line & 34.2 & 6.4 \\
Other & 7.9 & 15.1 \\
\hline
\end{tabular}

Most of the students chose to represent the fraction $4 / 5$ with parts of shapes. The rectangle and the circle were used by the largest number of students. All of these representations (rectangle, circle and set of objects) correspond to the part-whole subconstruct. Three students (3.9\%) from Slovenia and six students $(6.5 \%)$ from Kosovo used another type of fraction subconstruct 
- the division subconstruct:

they represented the fraction $4 / 5$ as division or as a decimal number (4:5 or 0.8$)$.

a) An example of using the division subconstruct (the second example in the picture - we have four pieces of cake and we divide them between five children. Each child gets $4: 5=4 / 5=0.8$ of...)

* 6. Predstavite ulomek $4 / 5$ na tri različne načine in pojasnite, $v$ čem se predstavitve razlikujejo.

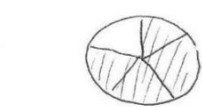

neravo

(1)

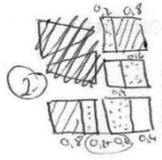

过

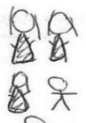

(1) Haloto, Ri ie ratdeliena na 5 delov. $\frac{4}{5}$ predstaviliaio 4 enalee dele te celcte (2) Imano 4 kose peciva, ki ga enakownerno ratdeliwo wad 5 droci -vsak dosi 0,8 kota. (4:5 $=\frac{4}{5}$ )

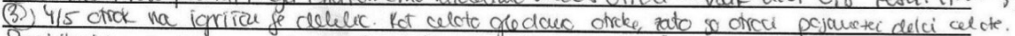

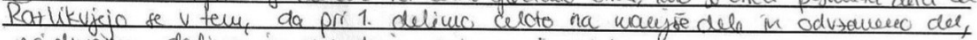

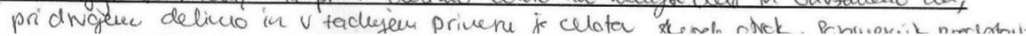

b) An example of using a shape for representing equal parts of the whole (the first and second example in the picture)

6. Paraqit thyesën $4 / 5$ në tri mënyra të ndryshme dhe shpjego si ndryshojnë këto paraqitje nga njëra tjetra.

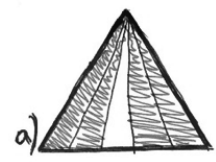

b)

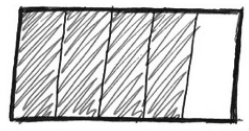

c)
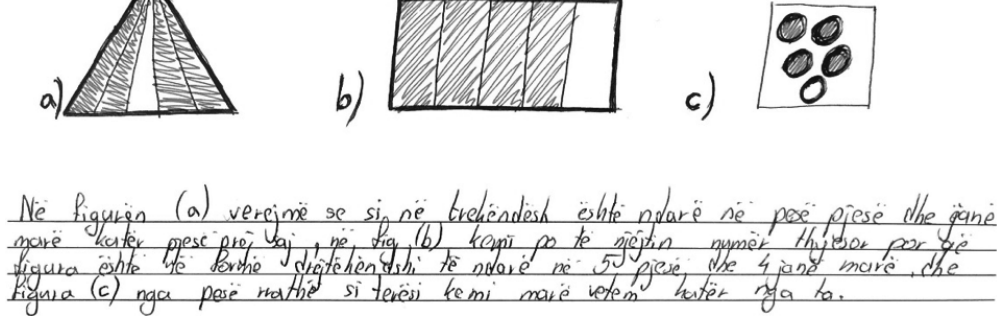

Figure 4. Samples of answers to Task 5: examples of primary teacher students' own representations of the fraction $4 / 5$.

The results again confirm our findings from the second research question: the rectangle shape is the most commonly used shape for representing fractions by primary teacher students.

Task 9 was a more a open problem. The students had to mark 2/3 of a rectangle in as many different ways as they could.

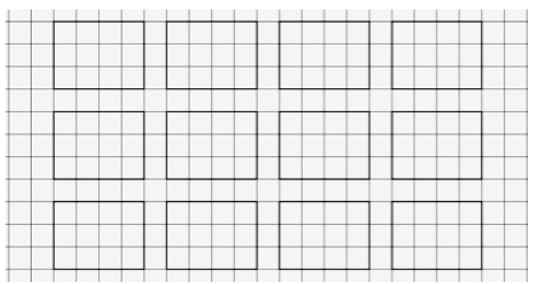


We categorised their solutions as follows:

Type A: Division into three congruent parts and then marking two parts that are adjacent

Type B: Division into three congruent parts and then marking two parts that are not adjacent

Type C: Division into non-congruent parts, the marked part is in one piece

Type D: Division into non-congruent parts, the marked parts form multiple pieces

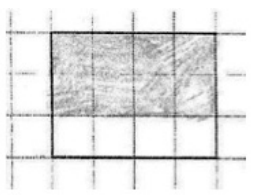

A

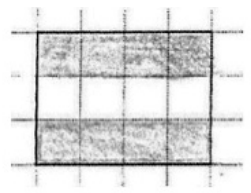

B

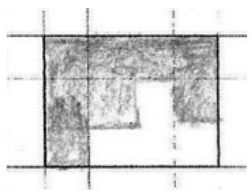

C

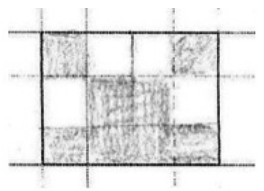

D

Figure 5. Examples for types A, B, C and D.

Table 6

Results for Task 9

\begin{tabular}{lcc}
\hline & $\begin{array}{c}\text { Slovenia }(\mathrm{N}=76) \\
(\%)\end{array}$ & $\begin{array}{c}\text { Kosovo }(\mathrm{N}=93) \\
(\%)\end{array}$ \\
\hline Type A & 97.4 & 83.9 \\
Type B & 56.6 & 73.1 \\
Type C & 92.1 & 49.5 \\
Type D & 53.9 & 20.4 \\
\hline
\end{tabular}

We can see that the Slovenian primary teacher students emphasised different characteristics of the representation than their Kosovar counterparts. Among the Slovenian students, types A and C prevail, which means that the shaded parts are adjacent. On the other hand, types A and B, which are based on division into congruent parts, prevail among Kosovar students. We can conclude that both groups of primary teacher students have some limitations in their conception of fractions. The Slovenian group places too much emphasis on the compactness of the fraction representation (in one piece), while the Kosovar group places too much emphasis on the congruent division of the whole. 


\section{Conclusion}

The conclusion will respond to the following research questions:

1. How do primary teacher students from Slovenia and Kosovo perform in tasks regarding the part-whole subconstruct of fractions?

2. In which "direction" do the primary teacher students perform better from part to whole or from whole to part using different representations of fractions?

3. How is the shape of the representation of the fraction related to the primary teacher students' success in solving the task?

4. What type of representations do the primary teacher students use for representing fractions?

First, we will discuss the comparison of results between the two countries and the reasons that affected the students' success in solving the tasks.

The results show that there is a significant difference between the success of the groups of primary teacher students from Slovenia and from Kosovo. The overall results show that the level of fraction knowledge possessed by the Kosovar students was much lower than that of their Slovenian counterparts. The Slovenian students performed better in almost all of the tasks.

These results are related to basic mathematics knowledge from the preuniversity education of students who typically enrol in the Faculty of Education in Kosovo. The same results were confirmed in the Programme for International Student Assessment (PISA) conducted in 2015. Slovenian students had a much higher level of mathematics achievement than their Kosovar counterparts in a representative national sample of 15-year-olds (OECD, 2016).

The second and third research questions relate to a detailed analysis of the tasks, which revealed that success in solving tasks on fractional representations is influenced by the type of representation and the shape of the representation.

The second research question deals with the role of the type of representation. The primary teacher students from both countries performed better in solving the tasks from part to whole than from whole to part in each of the three modes of fraction representation (area, sets of objects and number line). Comparison of the three different types of representation revealed that, on average, the primary teacher students achieved better results in number line representations than in shape or set of objects representations, with the difference being more significant among the group of Kosovar primary teacher students. 
Regarding the representations of fractions by area and set of objects, the students from Kosovo have misconceptions about the conceptualisation and coordination of multiple levels of units, which, according to Steffe and Olive (2010), reflects an inability related to advanced fraction schemes. However, the Kosovar students' understanding of fractions as measures seems to be clearer. Lamon (2012) explains that measure interpretation of fractions comes as flexible thinking during movement on a number line. Thus, the students from Kosovo used these interpretations to reason about relative size, fraction equivalence and the fractions' locations.

These results show that the primary teacher students had developed a certain level of fractional knowledge, as the most abstract representation does not present an obstacle to them. They seem to have developed an understanding of the measure subconstruct in which fractions are presented as abstract numbers. It is therefore even more unusual that problems with the part-whole subconstruct emerged (dividing the rectangle or the set of objects). We believe that the reason lies partly in the choice of fractions included in Tasks 1, 2 and 4: the students had to transform part of the whole and the whole in both directions, and the whole was greater than one. The tasks correspond to the coordination of the three levels of the unit (Hackenberg, 2007) and an iterative fractional scheme according to Steffe and Olive (2010), which is based on a splitting operation of the whole in order to achieve the unit fraction. We believe that when doing a splitting operation, more concrete representations, such as a rectangular shape or a set of objects, may become an obstacle to the solver, and that a reduced form of the representation, such as a number line, more easily directs the student to the important features of the procedure that has to be executed on the representation.

As mentioned above, the shape of the representation also influenced the success in solving the tasks (Research Question 3), with the rectangular shape proving to be the most successful shape. However, we should emphasise that the tasks with different shapes of representations also revealed certain misconceptions in the preservice primary teachers' understanding of fractions: the primary teacher students' belief that the part of the whole should be presented in one, compact part of the shape (Tasks 8 and 9), and also that the division of the whole into equal parts means dividing the whole into congruent parts (Task 9).

The fourth research question deals with the primary teacher students' own representations of fractions. The results of Task 5, where students had to present the fraction 4/5 with their own choice of representation, reveal just the opposite effect as was observed in Tasks 1, 2 and 4 . In this case, the students moved from using a number line representation back to shape and set of object 
representations. For both groups of primary teacher students, the rectangular shape of representation was the most commonly used model. These results were excepted, as the rectangle is the most frequently used model in primary school textbooks, and the students performed better with the rectangular shape than with the other models/representations (Alajmi, 2012; Charalambous \& Pitta-Pantazi, 2007). Only a minority of the students from both groups used a number line. In our opinion, this divergence shows that the part-whole subconstruct is still the basic subconstruct and primary teacher students tend to use it, albeit not exclusively. The usefulness of the number line representation becomes more evident with more demanding tasks, where the basic models for representing fractions lose their flexibility.

The insights gained in this study are limited. In order to obtain more in-depth information on primary teacher students' knowledge of fractions, further study should focus on a qualitative approach, such as interviews, which may help achieve a better understanding of how students explain and reason about the concept of fractions and their representations. An in-depth comparative analysis of curricula and textbooks for primary education would be necessary to determine factors that have an impact on the quality of teaching in primary schools in both countries.

The present study focused only on the part-whole and measure subconstructs. In future studies, the other subconstructs should also be considered in order to analyse their relationships, which should be used for deepening knowledge of fractions.

The study confirmed that the question as to what good mathematical knowledge is, or what mathematical knowledge prospective teachers need for teaching basic concepts, is very relevant. All of the students who participated in our research had completed mathematics in their final examination before entering university, and we should recognise that they possess mathematical competences at a certain level. On the other hand, we believe that, for successful teaching of mathematics in school, mathematical knowledge needs to be rethought. With all respect to students' mathematical knowledge, we have to find a way to diagnose their understanding of the concepts they are going to teach and to deepen their understanding or challenge their misunderstanding in the mathematics courses (mathematics and didactics of mathematics) that they attend in primary teacher training. As has already been stressed, teachers' knowledge of concepts directly influences children's knowledge; therefore, our (teachers at the faculties of education) main task is to empower our students, prospective teachers, with a deep understanding of basic concepts such as number, fraction, lines, arithmetic algorithms, solids, shapes, infinity, reasoning, 
etc. With such a goal, we can expect that teachers' competences, their awareness of what it means to be a responsible teacher who is able to organise situations for learning with understanding, will grow. According to Ball (2005), "teachers should understand the subject in sufficient depth to be able to represent it appropriately and in multiple ways" (p. 458). Programmes for teacher training for both preservice and in-service teachers should provide more opportunities for students/teachers to improve their basic knowledge of fractions, as well as of other relevant concepts.

\section{References}

Alajmi, A. H. (2012). How do elementary textbooks address fractions? A review of mathematics textbooks in the USA, Japan, and Kuwait. Educational Studies in Mathematics, 79(2), 239-261.

Ball, D. L. (1990). The mathematical understandings that prospective teachers bring to teacher education. The Elementary School Journal, 9o(4), 449-466.

Ball, D. L., Hill, H. C., \& Bass, H. (2005). Knowing mathematics for teaching: Who knows mathematics well enough to teach third grade, and how can we decide. American Educator, 29(1), 14-17, 20-22, $43-46$.

Barmby, P., Harries, T., Higgins, S., \& Suggate, J. (2009). The array representation and primary children's understanding and reasoning in multiplication. Educational Studies in Mathematics, 7o(3), 217-241.

Behr, M. J., Post, T. R., Harel, G., \& Lesh, R. (1993). Rational numbers: Toward a semantic analysis - emphasis on the operator construct. In T. Carpenter, E. Fennema, \& T. Romberg (Eds.), Rational numbers: An integration of research, (pp. 13-47). Hillsdale, N.J.: Lawrence Erlbaum Associates.

Bobos, G., \& Sierpinska, A. (2017). Measurement approach to teaching fractions: A design experiment in a pre-service course for elementary teachers. International Journal for Mathematics Teaching and Learning, 18(2), 203-239.

Castro-Rodriguez, E., Pitta-Pantazi, D., Rico, L., \& Gomez, P. (2016). Prospective teachers' understanding of the multiplicative part-whole relationship of fraction. Educational Studies in Mathematics, 92(1), 129-146. doi:10.1007/s10649-015-9673-4

Charalambous, C. Y., \& Pitta-Pantazi, D. (2007). Drawing on a theoretical model to study students' understandings of fractions. Educational Studies in Mathematics, 64(3), 293-316.

Chinnappan, M., \& Forrester, P. (2014). Generating procedural and conceptual knowledge of fractions by pre-service teachers. Mathematics Education Research Journal, 26(4), 871-896.

Clarke, D., Roche, A., \& Mitchell, A. (2007). Year six fraction understanding: A part of the whole story. Mathematics: Essential research, essential practice. Proceedings of the 30 th annual conference of the mathematics education research group of Australia (pp. 207-216). Adelaide: MERGA.

de Castro, B. V. (2008). Cognitive models: The missing link to learning fraction multiplication and division. Asia Pacific Education Review, 9(2), 101-112. 
Empson, S. B., \& Levi, L. (2011). Extending children's mathematics: fractions and decimals. Porstmouth, NH: Heinemann.

Hackenberg, A. (2007). Units coordination and construction of improper fractions: A revision of the splitting hypothesis. Journal of Mathematical Behaviour, 26(1), 27-47.

Hallett, D., Nunes, T., \& Bryant, P. (2010). Individual differences in conceptual and procedural knowledge when learning fractions. Journal of Educational Psychology, 102(2), 395-406.

Hamdan, N., \& Gunderson, E. A. (2017). The number line is a critical spatial-numerical representation: Evidence from a fraction intervention. Developmental Psychology, 53(3), 587-596.

Hill, H. C., Rowan, B., \& Ball, D. L. (2005). Effects of teachers' mathematical knowledge for teaching on student achievement. American Educational Research Journal, 42(2), 371-406.

Hill, H. C., Schilling, S. G., \& Ball, D. L. (2004). Developing measures of teachers' mathematics knowledge for teaching. The Elementary School Journal, 105(1), 11-30.

Keijzer, R., \& Terwel, J. (2001). Audrey's acquisition of fractions: A case study into the learning of formal mathematics. Educational Studies in Mathematics, 47(1), 53-73.

Kieren, T. E. (1976). On the mathematical, cognitive and instructional foundations of rational numbers. In R. A. Lesh (Ed.), Number and Measurement (pp. 101-144). Fonte: ERIC Document Reproduction Service No. ED 120027.

Kieren, T. E. (1993). Rational and fractional numbers: from quotient fields to recursive understanding. In P. T. Carpenter, E. Fennema, \& T. Romberg (Eds.), Rational numbers. An integration of research (pp. 49-84). New Jersey, NJ: Erlbaum.

Lamon, S. J. (2012). Teaching fractions and ratios for understanding (3rd ed). New York, NY and London, UK: Taylor \& Francis.

Lin, C.-Y., Becker, J., Byun, M.-R., \& Ko, Y.-Y. (2013). Enhancing pre-service teachers' fraction knowledge through open approach instruction. Journal of Mathematical Behavior, 32(3), 309-330.

Ma, L. (1999). Knowing and teaching elementary school mathematics (Vol. 1). New Jersey, NJ: Routledge. Manfreda Kolar, V., Janežič, A., \& Hodnik Čadež, T. (2015). Diagnosing students' difficulties in understanding the concept of fraction. In J. Novotna \& Moraova, H (Eds.), Developing mathematical language and reasoning (pp. 232-240). Prague: Charles University, Faculty of Education.

Moss, J., \& Case, R. (2011). Developing children's understanding of the rational numbers: A new model and an experimental curriculum. Journal for Research in Mathematics Education, 30(2), 122-147.

National Mathematics Advisory Panel (2008). Foundations for success: The final report of the National Mathematics Advisory Panel. Washington, D.C.: U.S. Department of Education.

Newton, K. J. (2008). An extensive analysis of preservice elementary teachers' knowledge of fractions. American Educational Research Journal, 45(4), 1080-1110.

Ni, Y., \& Di-Zhou, Y. (2005). Teaching and learning fraction and rational numbers: The origins and implications of whole number bias. Educational Psychologist, 4o(1), 27-52.

OECD (2016). PISA 2015 Results (Vol. 1): Excellence and equity in education. Paris: OECD Publishing. Olanoff, D., Lo, J.-J., \& Tobias, J. M. (2014). Mathematical content knowledge for teaching elementary mathematics: A focus on fractions. The Mathematics Enthusiast, 11(2), 267-310. 
Pantziara, M., \& Philippou, G. (2012). Levels of students' 'conception' of fractions. Educational Studies in Mathematics, 79(1), 61-83.

Park, J., Güçler, B., \& McCrory, R. (2013). Teaching prospective teachers about fractions: historical and pedagogical perspectives. Educational Studies in Mathematics, 82(3), 455-479.

Piaget, J., Inhelder, B., \& Szeminska, A. (1960). The child's conception of geometry. New York, NY: Basic Books.

Pothier, Y., \& Sawada, D. (1983). Partitioning: The emergence of rational numbers ideas in young children. Journal for Research in Mathematics Education, 14(5), 307-317.

Saxe, G. B., Taylor, E. V., McIntosh, C., \& Gearhart, M. (2005). Representing fractions with standard notation: A developmental analysis. Journal for Research in Mathematics Education, 36(2), 137-157.

Shulman, L. S. (1986). Those who understand: Knowledge growth in teaching. Educational Researcher, 15(2), 4-14.

Son, J.-W., \& Lee, J.-E. (2016). Pre-service teachers' understanding of fraction multiplication, representational knowledge, and computational skills. Mathematics Teacher Education and Development, 18(2), 5-28.

Steffe, P. L., \& Olive, J. (2010). Children's fractional knowledge. New York, NY: Springer.

Tsao, Y. L. (2005). The number sense of pre-service elementary. College Student Journal, 39(4), 647-679.

Tunç-Pekkan, Z. (2015). An analysis of elementary school children's fractional knowledge depicted with circle, rectangle, and number line representations. Educational Studies in Mathematics, 89(3), 419-441.

Understanding fractions: Interpretations and representations. An iTalk2Learn guide (2014). Retrieved from http://www.italk2learn.eu/wp-content/uploads/2014/11/Understanding-fractionsInterpretations-and-representations.pdf

Van de Walle, J. A., Karp, K. S., \& Bay-Williams, J. M. (2010). Elementary and middle school mathematics: Teaching developmentally (7th ed.). Boston, MA: Pearson Allyn \& Bacon.

Van Steenbrugge, H., Valcke, M., \& Desoete, A. (2010). Mathematics learning difficulties: Teachers' professional knowledge and the use of commercially available learning packages. Educational Studies, $36(1), 59-71$.

Van Steenbrugge, H., Valcke, M., \& Desoete, A. (2014). Preservice elementary school teachers' knowledge of fractions: a mirror of students' knowledge? Curriculum Studies, 46(1), 138-161.

Vula, E., \& Kastrati, J. K. (2018). Preservice teacher procedural and conceptual knowledge of fractions. In G. Stylianides \& K. Hino, Research advances in the mathematical education of pre-service elementary teachers (pp. 111-123). Cham: Springer.

Wilson, S. M. (2010). Knowledge for teaching mathematics in a primary school: Perspectives of preservice teachers. Canterbury, UK: University of Canterbury.

Yang, D.-C., Reys, R. E., \& Reys, B. J. (2009). Number sense strategies used by pre-service teachers in Taiwan. International Journal of Science and Mathematics Education, 7(2), 383-403. 


\section{Biographical note}

Vida Manfreda Kolar, $\mathrm{PhD}$, is an assistant professor in the field of didactics of mathematics on the Faculty of Education at University of Ljubljana, Slovenia. Her research interests include problem solving in mathematics, understanding of the concept of infinity and of fractions, the role of didactical material in teaching and learning mathematics and developing understanding of number in the early years of education.

TATJANA Hodnik ČAdEž, $\mathrm{PhD}$, is a full professor in the field of didactics of mathematics at the Faculty of Education, University of Ljubljana, Slovenia. Her main areas of research are: representations (external and internal) in teaching and learning mathematics, problem solving, students' understanding of complex mathematical ideas such as fractions, infinity, and more recently antropological theory of didactics of mathematics and professional developoment of teachers.

EDA Vula, PhD, is a full professor in the field of teaching mathematics and research in mathematics education in the Faculty of Education at the University of Prishtina in Kosovo. Her research interests include teaching and learning in mathematics, mathematical problem solving, action research and as well teacher education and their professional development. 